\title{
Global Perspectives on Youth Gang Behavior, Violence, and Weapons Use
}

Simon Harding

Middlesex University, UK

Marek Palasinski

Liverpool John Moores University, UK

A volume in the Advances in Psychology, Mental

Health, and Behavioral Studies (APMHBS) Book

Series

Information Science
REFERENCE

An Imprint of IGI Global 
Published in the United States of America by

Information Science Reference (an imprint of IGI Global)

701 E. Chocolate Avenue

Hershey PA, USA 17033

Tel: 717-533-8845

Fax: 717-533-8661

E-mail: cust@igi-global.com

Web site: http://www.igi-global.com

Copyright (C) 2016 by IGI Global. All rights reserved. No part of this publication may be reproduced, stored or distributed in any form or by any means, electronic or mechanical, including photocopying, without written permission from the publisher. Product or company names used in this set are for identification purposes only. Inclusion of the names of the products or companies does not indicate a claim of ownership by IGI Global of the trademark or registered trademark.

Library of Congress Cataloging-in-Publication Data

Names: Harding, Simon (Criminologist) editor.I Palasinski, Marek, 1981- editor.

Title: Global perspectives on youth gang behavior, violence, and

weapons use / Simon Harding and Marek Palasinski, editors.

Description: Hershey : Information Science Reference, 2016. I Includes

bibliographical references and index.

Identifiers: LCCN 2015046878I ISBN 9781466699380 (hardcover) I ISBN

9781466699397 (ebook)

Subjects: LCSH: Violence in adolescence. I Youth and violence. I Gangs--Case

studies.

Classification: LCC HQ799.2.V56 P79 2016 I DDC 303.60835--dc23 LC record available at http://lccn.loc.gov/2015046878

This book is published in the IGI Global book series Advances in Psychology, Mental Health, and Behavioral Studies (APMHBS) (ISSN: pending; eISSN: pending)

British Cataloguing in Publication Data

A Cataloguing in Publication record for this book is available from the British Library.

All work contributed to this book is new, previously-unpublished material. The views expressed in this book are those of the authors, but not necessarily of the publisher.

For electronic access to this publication, please contact: eresources@igi-global.com. 


\title{
Chapter 14 \\ From "Little Flowers of the Motherland" into "Carnivorous Plants": The Changing Face of Youth Gang Crime in Contemporary China
}

\author{
Simon Harding \\ Middlesex University, UK
}

\begin{abstract}
This chapter considers youth offending and youth justice in contemporary China noting significant changes due to the rapid economic transformation. Once famous for its low crime rates, the apparent rapid rise in Chinese juvenile delinquency has left the media "wondering what transformed these little "flowers of the motherland" into "carnivorous plants". The chapter charts changes from the yanda (hard strikes) crackdown in 1983 to the highly publicised anti-crime crackdown in Chongqing. Despite limited data, a picture is emerging of changing influence of triads and altered relationships between organised crime and street gangs, noting street gangs are increasing due to an influx of rural migrants to the mega-cities. The chapter touches upon the risk factors and emergent arguments of this contemporary phenomenon, noting that Zhang et al (1997:299) has suggested that 'China is in an early stage of gang development' possibly equivalent to the USA from 1930s to the 1960s.
\end{abstract}

\section{INTRODUCTION}

This chapter considers aspects of youth offending and youth justice in contemporary China which has been changing over the past two decades. In many ways youth offending is similar to that in the West, however recent rapid economic transformation has initiated rapid changes in the nature and presentation of youth offending. Once famous for its low rates of crime and juvenile delinquency, the apparent rapid rise in Chinese juvenile delinquency has left the media 'wondering what transformed these little "flowers of the motherland" into "carnivorous plants" in a country striving for a harmonious society", 
Box 1. From 'little flowers of the motherland' into 'carnivorous plants': the changing face of youth gang crime in contemporary China: Case study

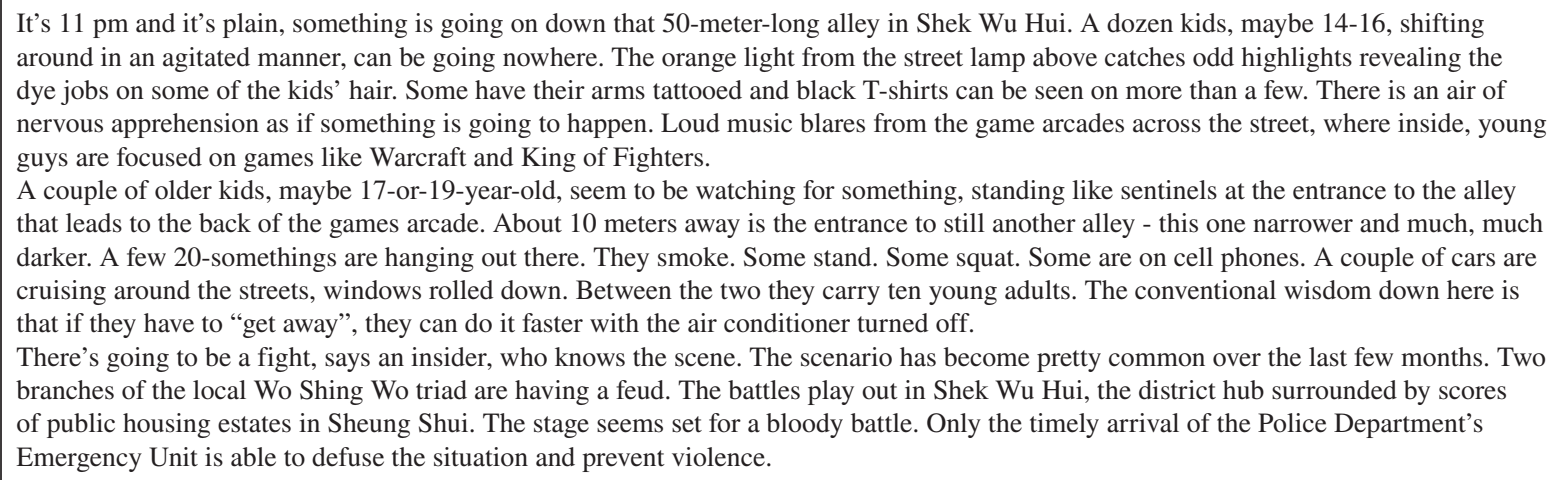

Source: Deng (2011) Bloody-minded youth, China Daily HK Edition 23 ${ }^{\text {rd }}$ June 2011

(China Daily $23^{\text {rd }}$ February 2013). The chapter charts changes over the past thirty years from the yanda (hard strikes) crackdown in 1983 to the contemporary and highly publicised anti-crime crackdowns in Chongqing. Despite some obscure Chinese data a picture is now emerging of changing influence of triads and altering relationships between organised crime and street gangs. After reviewing a typology of Asian gangs the chapter considers how street gangs appear to be on the rise in China largely due to the large influx of migrants from rural China to the rapidly urbanised mega cities. These issues are currently the centre of public debate in China and the chapter touches upon the risk factors and emergent arguments in relation to this contemporary phenomenon. Zhang et al (1997:299) has suggested that 'China is in an early stage of gang development' possibly equivalent to the USA from 1930s to the 1960s.

\section{Youth Offending and Youth Justice in China}

The above scenario in Hong Kong has become a noticeable and regular feature, particularly on many of the large public housing projects surrounding the city, notably the New Towns like Sheung Shui, Fanling, Tuen Mun, Tai Po, and Tseung Kwan O. Whilst generating much press and publicity they are indicators of changes taking place in the level, type and activity of youth street gangs in China. Lam Kin-keung, a retired detective station sergeant who spent eight years with the Organized Crime and Triad Bureau has noted that youth street gangs appear to flourish in such public housing neighbourhoods. Many affiliates of these groups are said to be instantly recognisable from their speech, their dress and their posture. Whilst some have direct, definitive links with triads, for others such links are obscured or more ambiguous. Regardless of this the consequence is often the same, young people coming together to fight with steak knives, clubs, and bottles or iron pipes.

Increasingly the participants are getting younger:

They are lost, suffer low self-esteem, come from poverty and abusive backgrounds. They are youngsters who can't find respect - with nowhere else to turn but to the triad societies who give them a sense of belonging they've never known before. Experts note a disturbing trend that recruits entering the triads are increasingly becoming younger. (Deng, 2011) 
Retired detective Kin-Keung suggests, "This is because the gang leaders of different factors (branches) - whether they belong to the same triad tong or not - are having more and more direct control over their followers than the dragon heads do. In order to augment their power, the gang leaders have to recruit lots of deviant kids," Continuing his observations he noted that "The phenomena of the triad committing crimes in recent years shows not only more active moves among lower level of triad members, but that they are younger. The expansion of a triad branch can happen very quickly. And the way they commit crimes is getting more ferocious", (Deng 2011-06-23).

Youth crime in China has been changing for the past two decades; however indications are that these changes are now faster and more profound, leading some public debates to question what has happened to Chinese youth? The headline for the China Daily in 25th June 2015 declared 'String of youth violence cases shocks nation'. The article quoted a survey by the China Youth and Children Research Centre stated that juvenile delinquents were getting younger with more crime linked to drugs and internet use: of China's 279 million juveniles, more than 70 per cent of crimes in 2014 were committed by young people aged between 10 and 25 yrs. The report also emphasises aspects of a 'moral deficit in parenting', (China Daily 25th June 2015).

Migration from rural to urban China is also a causal factor for increased delinquency. The sociology professor at Central China Normal University, Mei Zhigang, says that increasingly juvenile delinquent behaviour in China is being conducted in groups and that this often involves violence, drugs or sexual abuse. He noted that young offenders are often children of the 'left behind' migrant children population, now nearing 100 million, (China Daily 23rd Sept 2013).

Once famous for its low rates of crime and juvenile delinquency, the apparent rapid rise in Chinese juvenile delinquency has left the media "wondering what transformed these little "flowers of the motherland" into "carnivorous plants" in a country striving for a harmonious society', (China Daily 23" February 2013).

In many ways youth offending in China echoes that of the Western industrialised countries, according to Shen and Hall (2015). Their study explores the philosophical bases, policy and practice of Chinese youth justice and contextualises the pattern and nature of youth offending in contemporary China. Whilst they note that Chinese youth justice does not differ formally from that of the Western nations, they recommend the suspension of assumptions when considering the situation in China.

Data on juvenile offending and youth crime can be difficult to locate and that which is available appears to indicate rising levels of youth offending. China's courts sentenced 322,061 juvenile's in 2008, 88,891 of whom were minors under 16 , a 1.58 per cent increase year-on-year and making up 32 per cent of overall convictions nationwide. Numbers of juvenile crimes nationwide were 41,763 in 2000, rising to 58,870 in 2003 and 71,472 in 2005. In terms of crime types, robbery accounts for 35 per cent of all juvenile crimes and theft for 38 per cent. Fighting and quarrels were listed as 8 per cent and gang brawls for 4 per cent. In Shenzhen, 98.55 per cent of juvenile crimes were committed by youngsters without a local government household registration, (i.e. migrant), (China Daily - People's Court Review 7th May 2009).

The issue of rising crime levels in China is once more high on the public, government and media agenda. In 2009 one headline in the China Daily announced that 'Crime is a risk to stability: Official'. It claimed that 'China faces an uphill battle to maintain social stability this year as crime figures continue to rise, according to the country's top judicial leaders', (China Daily, 16th Feb 2009). This led to calls to improve the system of prosecution, notably at district and county level and also to calls to guard against corruption. Similar headlines continue to appear driving national debates and influencing the public 
mood, often constructing crime as a threat to national security and social harmony. In 2015 the China Daily headline noted 'Gang activity in Guangdong poses 'serious threat' - Lin Weixiong, Director of Criminal Investigations Bureaus under the Guangdong Dept. of Public Security, stated that task forces were needed to fight gangs involved in drugs, counterfeiting and vote-buying in local elections. This was considered to be a 'serious threat to grassroots governments and organisations' this often interfered with township and village elections', (China Daily, 10 ${ }^{\text {th }}$ July 2015).

However this is not the first time that crime rises hare garnered news headlines prompting policy outcomes. In fact, periodic crime upswings have been a topic of public debate for the past 30 years. After the commencement of Communist rule China often pro-claimed its success as an almost crime-free society. Against this backdrop, and a baseline of close to zero, any increase in offending might seem not only notable, but potentially alarming. As such, increased crime and rates of crime has become one of many factors arising from rapid urbanisation and significant social change occurring in China. For many, it is a consequence of the speed of change; for others, it is more a symptom of the type of changes occurring and the inequalities arising from these changes. The reaction to these periodic upswings in crime has on occasion been for the central government to initiate a 'crackdown' on crime which for many observers is an opportunity for tighter social control. For example, one such crackdown was announced by Vice-minister of Public Security, Zhang Xinfeng, in the run up to National Day. His announcement instigated a five month nationwide campaign to improve public security in the run up to the 60th anniversary of the found of the People's Republic. The campaigns which involved a crackdown on both gangs and organised crime had the stated aim of 'harmonious social environment', ('Crackdown on crime in run-up to National Day', China Daily 28th April 2009).

Not all academics are in agreement that crime rises have in the past been real statistical events. Bakken (2004) in his analysis of China's criminal justice system argues that a critical examination of China's crime rate does not, for example, support the belief that a crime surge took place in the 1980s. During the early 1980s as economic policies became increasingly liberalised and progressive, China underwent what he describes as a 'moral panic about juvenile crime'. Arguing against any evidence pointing towards a 'surge' in crime, he argues that any rise would be a natural occurrence given the rapid urbanisation and population growth, including the maturing of the Chinese Baby boomer population into adolescence, e.g. the population of 14-25 yr olds in China rose dramatically from under 120 million to 272 million in 1987, (Bakken, 2004). He contends that the various anti-crime campaigns which are subsequently undertaken are linked instead to the legitimacy requirements of the communist party regime and its stated defence of the social and moral order of a society undergoing rapid social change.

One such anti-crime campaign undertaken in 1983 was the yanda (hard strikes) anticrime campaign. Bakken (2004) claims this was caused largely by a moral panic about youth crime, particularly targeted youth gang leaders (touzi) rather than corrupt officials or illicit entrepreneurs. Bakken claims the regime needed to demonstrate authority and control in society and boost its legitimacy whilst undertaking market reforms.

Under the hard strikes campaign the harshest punishments, including capital punishment, were often conducted in public. This included the execution of gang leaders in an attempt to dissolve gangs and eliminate gang recruitment. Summary trials were held of gang leaders aged 16 and over and this became a conspicuous feature of the campaign (Bakken 2004). In 2009, The Yangjiang Municipal Intermediate People's court passed death sentences on five people for the murders of four others by a 43 strong criminal gang. Two were also fined 310 million yuan (US\$45.4 million) and 325 million yuan. The gang 
had admitted involvement in tax evasion, illegal gambling dens, extortion and lynchings, issuing false invoices and using guns for enforcement, (China Daily 4th Dec 2009).

The true picture here is sadly somewhat obscured as Chinese data is unreliable and often politically and socially constructed, including manipulation and 'creative accounting' of crime figures. Bakken is critical of this form of 'penal populism' directed by Deng Xiaoping, but accepts that penal populism 'has a strong foothold in China, (Bakken 2004, p80). Setting the data aside, such policy responses set the template for government reaction to rising crime rates and creating the timely space for political opportunism.

Despite the anti-crime campaigns of the early 1980s the effect on crime itself was clearly limited as more often than nought such criminal gangs and networks survived and thrived. In 1989 a three volume report on crime by the Chinese government identified an increase in gang crime and linked the rises to modernisation and the relaxation of state control. The report identified 36,000 gangs and 138,000 gang members, active in China (Dutton 1997). This compares with analysis in the USA (Egley \& Howell 2011 as cited in Pyrooz \& Decker 2013, p254) which suggests that there are 28,100 gangs and 731,000 gang members operating in the USA.

By the 1990s the evidence of increased juvenile delinquency in China was all pointing in one direction. By 1999, Wong (1999), and other academics as Zhang (1997; 1998), were in agreement that the improvement and growth in the Chinese economy has led to a genuine statistical increase in delinquency. The increase in juvenile delinquency has also impacted upon the criminal justice and youth justice provision. The Juvenile Protection law (1991) and the Preventing Juvenile Delinquency law (1999) were established to set out and define the duties, responsibilities and authorities of parents and guardians regarding child welfare, education and juvenile justice. Wong also notes that with these new laws there is a noticeable shift from the traditional Chinese model of informal intervention to a more formal structured intervention of delinquency control which might lead to increased custodial sentences for young offenders, (Wong 2004). In China both informal grassroots networks and formal correctional institutions both have a role to play in controlling delinquency. Wong (1999) however contends that the development of fair and independent juvenile justice systems is hampered by low levels of skilled manpower and frequent volunteers staff turnover compounded by the relationship between the control systems and the Communist party machine.

Zhang (1997) advises that research on juvenile justice and delinquency remain largely descriptive with scant trend analysis. In 2001 the China Daily was already reporting the need for improved and increased probation services to curb the rising tide of juvenile delinquency, (China Daily 17th Feb 2001).

Coupled with debates about increased delinquency amongst juveniles have been high profile drives against corruption and diminishing trust in the Chinese police, particularly in urban areas, (Wu, Sun, $\mathrm{Hu}$, 2015). Trust varies considerably across the key urban cities and some observers and academics consider China to have a 'crisis of legitimacy' regarding its police service, (Sun, $\mathrm{Hu}, \mathrm{Wu}, 2012$ ).

Fast forward to 2014/15 and Chinese societies have witnessed a dramatic growth, not only in social and economic terms but in terms of youth crime and delinquency (Xi, 2001; Ngai 2004; Zhang et al, 1993). In China researchers report that the growth of crime and delinquency is largely down to the rise in gang involvement of delinquent youth and that much crime in China involves delinquent youth (Xi 2001).

Public debates, press and media coverage and academic research now centres on the following contributory issues and outcomes: changes in the activities of organised crime networks and the loosening power of the triads; the emergence and expansion of drug trafficking and new drug markets; the role of rural-urban migration and deprived migrant youth; the emergence of youth street gangs; the expansion 
of youth street gangs in urbanised areas of china and issues of parenting and social control. All of which has taken place as a consequence of rapidly changing socio-economic conditions arising from market liberalisation. This chapter will examine each of these above points in more detail.

Before we focus on China, it is important to consider how Asian gangs are researched and studied and to clarify what is known about different types of youth gang and organised crime group operating in Asia.

\section{Studying Gangs and Organized Crime in Asia and China}

Criminology in China, and other parts of Asia, remains a fairly nascent discipline. Academic and institutional research however remains many years behind that of the West. Despite this fact, an emerging body of Chinese criminological studies (Chin 1990; Chin, Huang 2007, Kelly \& Fagan 1993; Liu 2004; Song \& Dombrink 1994; Song 1996; Wang et al 2002, Wang 2013, Zhang 2014, Zhang et al 1997, Zhang et al 2008, Zhou et al 2004) is expanding the knowledge base and opening up the debates on the applicability of Western theory to occidental social and geo-political conditions. Research into Chinese gangs is similarly engaged and is beginning to present insights into rising delinquency, risk factors for gang affiliation, youth gang involvement, links to organised crime and gambling syndicates, government crackdowns and punitive responses. The Challenges of conducting such research in China are exacerbated by numerous methodological barriers which in many ways need ways of thinking to overcome them. One key issue in China is differentiating between normative youth behaviour, youth criminal activity, youth street gangs and organised crime linked to, or not linked to, national, or even international, crime syndicates. This confusing picture is central to an understanding of crime in China.

Whilst gang research in the US benefits from a long and informed academic tradition, US gang research into Asian gangs and organised crime operating in the US, lags somewhat behind. This is partially explained by various methodological challenges facing those studying Asian gang active in the US, (Song, 1996). Some of these issues identified by Song, (and listed below), will doubtless be pertinent in gang research in Asia and specifically China, namely:

- The unique cultural characteristics and modus operandii of the various criminal groups operating in Asia differs hugely - e.g. drug trafficking groups, Japanese Yakuza, Vietnamese gangs; Tongs, Triads; Taiwanese immigrant gangs; Korean gangs, etc. Thus an understanding of domestic and also international cultural interactions and geo-politics is required.

- The various groups such as organised criminal gangs, triads or underground societies, tongs, gangs, etc, all require accurate classification before research can effectively be undertaken.

- There is a need to re-examine the boundaries of these groups, especially the interfaces between youth gangs and organised crime when talking of Asian crime groups

- Language and cultural barriers are frequently exhibited in Asian gang research with China for example having four major dialects. (In the USA, Asian communities have 34 distinct ethnic groups and even term Asian is unhelpful).

- In the absence of data and reports from NGOs, secondary analysis is often over-reliant on media and public documents

- There are no systematic efforts to evaluate the effectiveness of enforcement measures against gangs or organised crime. 
From "Little Flowers of the Motherland" into "Carnivorous Plants"

- There is a lack of availability of public documents regarding key data and statistics for example, migration patterns, policing operations, recorded ethnicity, levels of crime reporting and crime recording, etc.

- The exclusive nature of migrant communities and the hidden and secretive nature of organised crime remain a further barrier to research on gangs and organised crime.

It is important to address such methodological deficits for research into Asian groups and organised to move forwards.

\section{Typology of Gangs in Asia}

The study of Asian gangs requires clarity regarding the boundaries of the various different criminally active groups. Whilst issues of definition continue to consume Western academics and defy consensus, some similar challenges occupy academic study of Asian criminal enterprises. Most academics focus specifically on one type of criminal enterprise and few have sought to classify Asian gangs or to arrange them on a spectrum which might help clarify for the lay-person the activities, and the networked connections, if any, operating between them. Hua-Lun Huang's (2007) work is one exception to this as he has tried to offer a typological analysis of Delinquent Asian gangs.

Huang argues that differences in gangs are relative and not absolute. He offers a typology of Asian gangs based on three factors - political belief, organisation level and structure and political connection. Thus he identifies 8 different types which operate or have operated in Asia. Delinquent gangs here refer to 'three dissimilar but comparable associations, namely delinquent groups, street gangs, and organized crime 'enterprise', (Huang 2007, p129). He then takes the three categories of political belief, organisational structure and political connection and sub-divides them into two different levels: 'salient/inconspicuous ideology for political belief; tiered/egalitarian organizational arrangements for organisational structure, and patron-client/ no patron-client relationship for political connection', (Huang 2007, p130). Based on these different combinations he offers a classification system for the different types of Asian gangs. This helps differentiate quasi-political or ideological groups from street based groups.

Huang suggests that those groups with a salient ideology should be considered as expressive groups or 'dreamseekers' attempting to realise a stated long-term goal. Those with an inconspicuous ideology however are instrumental groups interested in pursuing economic goals. He claims this classification allows for all historical or contemporary groups to be accounted for, (Huang 2007).

Huang adopts a typological approach to gang classification arguing that gang appearance and growth is linked to territorial expansionism, nationalism, religious extremism of other similar ideology. He suggests that this typology approach is more comprehensive, and therefore more suited to Asia, than typologies based on the Chicago School ecological paradigm. Table 1, below, illustrates the various groupings identified by Huang.

For those seeking to understand the key differences between the active criminal groups in Asia and to familiarise themselves with the range of activity, this is useful starting point. However as a conceptual tool it is useful in elucidating distinctions between various groupings. Certainly the focus on ideology is helpful in explaining why certain gangs have an extenuated lifecycle but it is also helpful in understanding how gangs operate, recruit and conduct business. This chapter shall now focus or the issues of organised crime in China, starting with the role of the 'dark societies' or triads before considering the links between triads and street gangs. 
Table 1. Typology of Asian Gangs

\begin{tabular}{|l|l|}
\hline \multicolumn{1}{|c|}{ Type } & \multicolumn{1}{c|}{ Example } \\
\hline $\begin{array}{l}\text { Salient ideology + tiered structure + patron-client relationship in } \\
\text { politics }\end{array}$ & $\begin{array}{l}\text { The Black Dragon Society. An ultra-nationalist organisation } \\
\text { formed in Japan in 1901 }\end{array}$ \\
\hline $\begin{array}{l}\text { Salient ideology + egalitarian structure + patron-client } \\
\text { relationships in politics }\end{array}$ & $\begin{array}{l}\text { Chinese triads. Loosely structured groups of ultra-rightist } \\
\text { nationalists. }\end{array}$ \\
\hline $\begin{array}{l}\text { Salient ideology + tiered structure + No patron-client relationship } \\
\text { in politics }\end{array}$ & $\begin{array}{l}\text { Abu Sayyaf guerrilla/pirates active as Islamic insurrectionists } \\
\text { in the southern Philippines engaged in banditry, kidnapping and } \\
\text { piracy. }\end{array}$ \\
\hline $\begin{array}{l}\text { Salient ideology + egalitarian structure + No patron-client } \\
\text { relationship in politics }\end{array}$ & $\begin{array}{l}\text { The Seven Princesses (female) gang in Korea. Those who operate } \\
\text { as 'social bandits', peasant robbers or 'virtuous Robin Hoods'. }\end{array}$ \\
\hline $\begin{array}{l}\text { Inconspicuous Ideology + tiered structure + patron-client } \\
\text { relationship in politics }\end{array}$ & $\begin{array}{l}\text { Yamaguchi Gumi of Japan. Partially hidden hierarchical crime } \\
\text { syndicate. }\end{array}$ \\
\hline $\begin{array}{l}\text { Inconspicuous ideology }+ \text { egalitarian structure + patron-client } \\
\text { relationship in politics }\end{array}$ & $\begin{array}{l}\text { Sun Yee On - the largest and most powerful Triad society of Hong } \\
\text { Kong. Operates with less bureaucracy than the organised criminal } \\
\text { enterprise of the Yamaguchi Gumi. }\end{array}$ \\
\hline $\begin{array}{l}\text { Inconspicuous ideology }+ \text { tiered structure + No patron-client } \\
\text { relationship in politics }\end{array}$ & $\begin{array}{l}\text { Organised pauper gangs or gai bang. These organised beggar } \\
\text { rings act a street families and are often headed up by a senior male } \\
\text { beggar or 'grandpa' who ensures the group finds food, shelter and } \\
\text { work. }\end{array}$ \\
\hline $\begin{array}{l}\text { Inconspicuous ideology }+ \text { egalitarian structure + no patron-client } \\
\text { relationship in politics }\end{array}$ & $\begin{array}{l}\text { Chinese, Chinese/Vietnamese or Southeast Asian gangs operating } \\
\text { in the US and Canada. No associated to tongs, these are profit } \\
\text { oriented street gangs raising in income from drugs, vice fraud and } \\
\text { gambling. }\end{array}$ \\
\hline
\end{tabular}

Source: Huang (2007) From the Asian Boys to the Zhu Lian Bang (the Bamboo Union Gang): A Typological analysis of Delinquent Asian Gangs. Asian Criminology 2: 127-143.

\section{Street Gangs vs. Organised Crime}

Distinctions between street gangs and organised crime groups was first identified by Thrasher in 1927, followed by others such as Cloward and Ohlin (1960), Spergel (1961), Potter (1994), Klein (1995), and Varese (2006). Assessing and clarifying the differences became important for academics and also for the criminal justice system in terms of enforcement and sanctions. Research into US gangs by Jankowski (1991) noted key differences between street gangs and organised crime at the upper level whilst there was also differences between street gangs and 'crews' or groups of youth operating at the lower level. Curry, Decker and Pyrooz (2014) argue that criminal activity operates on a spectrum from disorganised street gangs up to organised crime and gangs both vary and evolve overtime. In this way Western theory and research echoes the views of Huang and his conceptualisation of the Asian typology and context. As in Western gang research it is still important, if not critical, to distinguish between street level criminal groups and organised crime.

Varese (2010) describes organised crime as specialised networks that rely upon expertise, rather than hierarchy, to undertake criminal activity for financial gain. Recent changes in society have possibly added a further level of distinction between street gangs and organised crime for example, international or transnational organised crime groups increasingly utilise information technology and now often operate, as Dishman (2005, p237) describes them, as a 'leaderless nexus'. 
The high-level organised crime syndicates in China differ considerably from youth street gangs, operating secretly and managing huge financial deals; it is in their interests to maintain a low profile. The principal criminal activity of these groups is gambling and its associated activities including vice and money laundering. In 2009 during a money laundering trial 22 organised crime members, including a local policeman were charged and sentenced for using threats of violence to compel trade, extortion, assaults, actual bodily harm, prostitution, false accounting and gambling since 2003, (China Daily, 16th Dec 2009).

Since 2006 Beijing courts have convicted 12,796 people in connection with 1,171 cases of organized crime according to the Supreme People's Court. Of these 4 per cent were sentenced to more than five years in prison. These figures relate to the nationwide crackdown on organized crime instigated early in 2006 to July 2009. Police had investigated 1,267 organised crime cases and disrupted 13,000 gangland organisations. Of these more than 400 were involved in construction, mining and wholesale sectors with the proceeds of these exceeding 4 billion yuan (US\$588million). The investigations also included 108,000 other cases including 419 homicides and more than 10,000 assaults. Authorities claimed these results had led to a decrease in violent crime such that by 2008 violent crime was down 11 per cent compared to 2005 (the year prior to the campaign) with 2,700 firearms also seized, (China Daily \& Xinhua 1st Sept. 2009).

The Deputy Director of the Criminal Investigation Bureau of the Ministry of Public Security (MPS) said 'gangdom is still active in China', noting that gangsters often operated under the 'protective umbrella' of government departments and judiciary departments. From February 2006 and July 2009 Chinese prosecutors authorised the arrests of 44,319 people involved in 9,000 gang crime cases. Of these 42,000 were successfully prosecuted with more than 1,300 sent to labour re-education camps, (China Daily \& Xinhua 1st Sept. 2009).

Re-education camps are strictly controlled by tight legal procedures and offenders are designated to the camps following an initial proposal from the police. This proposal is then approved by the labour camp management committee which consists of officials from the judiciary, labour, personnel and public security departments alongside representatives from workers, youth and women's organisations. Detention is supervised by prosecuting agencies. Gang members who are detained in prisons by the Ministry of Justice are purposefully located in prisons outside their home region to reduce opportunities for contact with previous accomplices and to disrupt their networks. Upon release they are subject to stricter parole and probation conditions, (China Daily \& Xinhua 1st Sept. 2009).

\section{Gambling}

All gambling in mainland China was outlawed until the first welfare lottery was established in 1987. Despite this gambling socially has long been a Chinese social pastime.

In 1978 China's 'open door' policy and subsequent economic reforms made profitable economic development and entrepreneurship a national goal, (Liu 2008) and this came a massive expansion of illegal gambling. However the race for profits, now nationally sanctioned, opened the door for numerous 'get rich quick' schemes. Numerous opportunities now presented for illicit enterprise. To understand this complex picture more clearly it is useful to consider in more detail how gambling works and how it offers illicit business opportunities for the triads. 
Three types of gambling schemes operating in China by organised crime syndicates have since been identified (Wang and Antonopoulos (2015): - local gambling dens; trans-regional gambling rings and online gambling networks. Each of these enterprises strategises to optimise the most favourable financial returns in the face of police surveillance and suppression.

Wang and Antonopoulos (2015) note that 'in a country such as China where the legal system is weak and the working of the government is opaque, personal connections (guanxi) have become extremely important in various aspects of Chinese business and personal life, including illegal activities, (see also Broadhurst 2012). Gaunxi helps to identify customers, partners, and players and also helps to recover debts. It may also help secure financing, resolve disputes and obtain police protection, (Wang \& Antonopoulos 2015). Guanxi is the key resource for running these connections and acts as both social glue for personal and professional connections but also social lubricant for all transactions.

In the traditional off-shore gambling haven of Macau four major crime syndicates are involved in rolling or exchanging chips. They have all set up sub-branches or agencies in mainland China or they link up with mainland Chinese gangs in order to recover debts (Varese 2011). Debt collection is undertaken by criminal gangs and may involve abduction, assault, torture blackmail and murder. Many businesses try to keep face or (mianzi) and so will pay up through the guanxi networks, (Wang \& Antonopoulos 2015).

The Chinese government are aware of such criminal syndicates and have recently acted to disrupt and destroy them.

\section{Periodic 'Crackdowns'}

To address the issues of organised crime and the rise in youth offending about gangs, periodic 'crackdowns' are initiated by local and by central government.

In 2006 China instigated a 'crackdown' on criminal activity leading to the prosecution of upwards of 70,000 gang-related crimes between 2006 and December 2008. This 'crackdown' led to a reduction in murder, robbery and physical assaults of approximately 4 per cent for two years. Data from the Supreme People's Court indicated that 337 gang crimes were processed in 2007 which was up 161 per cent year on year. In 2006 and 2007 more than 6,000 criminals received sentences for gang-related offences. Professor of Criminal Law at China University of Political Science, Liang Huaren echoed the comments from the Director commenting that the upsurge in gang-related crime was related to the changing economic and social landscape of China which exacerbated growing inequalities and which were most noticeable between unemployed workers and migrants and others. Whilst gangs and organised crime were clearly linked together and in places indistinguishable, it was suggested that the traditional gang activities of prostitution, gambling, drug production and trafficking were being supplemented by new criminal activity in the construction industry, transport and mining sectors. Money disputes often provided opportunities for gang involvement which then led to racketeering. Gangs were also thought to seek protection by establishing close business links with government officials and corrupt police officials, (Zhu Zie, China Daily, 22nd Dec 2008).

By 2008 China was planning a 'special unit to tackle gangs' - identified as organised criminal groups. Speaking via the China Daily a senior official of the Ministry of Public Security (MPS) said, 'A new division is being planned to combat growing mafia style gangs in the country'. The director of the ministry stated that the fight against gang crime would be a 'lasting task' and sought new legislation to address the issue. Continuing, he said, 'gangs will remain active as the country undergoes dramatic 
social and economic changes'. He went further by saying, 'Gang related crimes have become a threat to our social stability and the economy', (Zhu Zie, China Daily, 22nd Dec 2008).

In June 2009 authorities in Chongqing instigated a high profile crackdown on organised crime in the city involving 3,000 police, the aim being to dismantle gangs in the city. By August 2009 police had detained 1,544 suspected gangsters from 14 organised gangs with a further 469 suspects still at large. During this crackdown multiple firearms, ammunition and assets were retrieved. Liu Guanglei, Team leader of the city's campaign against organised crime was quoted as saying, 'Chongqing will struggle to stay safe if we don't crack down on the organised gangs'. Xinhua News Agency was quoted as reporting that 'scores of police officers also accused of protecting criminal gangs have been detained'. It was also reported that local citizens helped in this crackdown by providing useful tip offs, (China Daily 18th August 2009).

Similarly from August to September 2009 police in Guangdong province, Hong Kong and Macao worked in partnership to break up more than 1,340 gangs and address cross-border crime. This operation included 1,872 cases connected to triads and targeted phone and online scams as well as drug manufacturing and trafficking. A total of 8,139 suspects were detained alongside 185 unlicensed firearms and 7.15Million yuan (US\$1.05million), (China Daily 25th Sept 2009).

A further notable 'crackdown' was in Chongqing where multiple premises were closed following a high profile intervention organised by the Chongqing government from June 2009 - Nov 2011, (Broadhurst 2013; Wang 2013). The Chongqing crackdown became the most high profile 'anti-mafia campaign' in China and was reported worldwide. It was aimed at putting local criminal organisations out of business whilst offering opportunities to crusade against key influential business and senior government officials under whose auspices the syndicates flourished, (Broadhurst 2013; Broadhurst \& Wang 2014).

\section{Triads}

One element of organised crime instantly recognisable as associated with China is that of the triads. The Term triad (which is actually English) describes 'dark societies' but overtime has become synonymous with organised crime in China. However, there is considerable imprecision when trying to describe or define both organised crime in China or triads, (Broadhurst \& Wa, 2009).

China has a long tradition of triads or semi-secret societies. These were originally formed several hundred years ago as underground political agit-prop groups and have evolved into large societal organisations in most Chinese societies, in China and overseas. Traditionally these organisations of adult men operated as nationalistic or quasi-political societies before transferring into quasi-governmental groups exacting strong-arm functions for various regional administrators across China. After a higher profile involvement in the Boxer Rebellion they retreated into more secretive criminal underworlds from the mid $20^{\text {th }}$ Century. They also have a long history relating to repeated waves of Chinese immigration entering Hong Kong and this has permitted them to maintain recruitment, power and influence.

In communities such as Hong Kong, which are overwhelmingly established and composed of immigrants, the social networks afforded by triad societies was invaluable and the triads offered migrants protection to those vulnerable to unemployment or social exclusion.

Essentially triads now operate as hierarchical organisations offering entrepreneurial opportunities for organised criminal ventures in China, but also in the SE Asia where significant Chinese populations are domiciled, (Chin 1990a; Chin 1986). Famously triads also operate in the USA. 


\section{Triads in the US}

Importantly similar methods of extortion operate in the United States Chinese community largely operated via the triad societies, (Kelly, Chin, Fagan, 1993). In comparing Chinese gangs in New York City, Chin (1990) identifies several distinctive factors which differentiate Chinese gangs from those of Black, Hispanic or Italian decent. Namely they have their origins in the social and cultural life of the immigrant communities rather than youth fads, fashion or drugs. This facet leads to gangs becoming deeply enmeshed in local business - both legitimate and illegitimate - offering opportunities for financial, social and cultural advancement. This is quite separate from how gangs operate in other communities. The influence of triad society within wider communities is another key difference.

The Asian gangs operating in the US do not necessarily operate in the deprived urban communities typical of black or Hispanic gangs, but instead thrive in Chinese communities which present multiple and varied business opportunities. Chin (1990) notes they are embedded in the triad subculture which is constructed and maintained by secret Chinese societies. Chinese gangs in the US are therefore able to copy or adopt similar practices as operated by triads in China and then claim hereditary rights and links to triad societies. In this way triad norms can be adopted and offer a form of internationalised triad activity including adopting rituals and initiation rites. This tactic permits them to be viewed by the Chinese community as something more than simple street gangs offering certain legitimacy and even romantic historical provenance, (Chin 1990). This in turn creates a shroud of mystery and cultural significance which often generates high levels of fear and intimidation amongst local Chinese populations. This generates an influence which is based on more than violence and thus again it differs from other ethnic gangs. Chin (1990) also suggests that in some places these triad connections are loosening and may change in the future, with the possibility of Chinese gangs adopting and more international street gang flavour. Vietnamese gangs and Fujianese gangs now operate outside of the triad sub-culture and their involvement in street robbery and burglary again distance them from the traditional triads.

\section{Triads in Southern China and Hong Kong}

Triad activity includes racketeering and protection in all its forms with local small business including taxis, restaurants, street hawkers and local shops suffering either extortion or enforced price fixing. Alongside extortion often sits money lending, loan-sharking and then debt collection. Drug sales 'patches' or turfs are sometimes sold to street gangs as part of the drug distribution network. Commercial vice operations such as prostitution, sex shops, brothels, gaming halls are targeted alongside more legit operations such as karaoke bars and nightclubs. Hong Kong triads are actively involved in the operation of night-time economy outlets such as saunas, nightclubs, bars, and lounges often operating with an affluent clientele. Hong Kong merchants often report difficulties in conducting business expansion and may find their business investment put at risk due to triad gangs seeking to engage in coercion or extortion for rival companies or groups.

Construction sites, waste disposal and transport groups can be subject to monopoly control and intimidation even takes place within the film industry in Hong Kong. In addition loan-sharking, debt collection, drug trafficking and gambling in various forms are considered natural criminal turf for the triads. Counterfeit production of perfumes, cigarettes and fuel smuggling are relatively new additions and now sit alongside prostitution and pornography as opportunities for generating profits. Opportuni- 
ties for profiteering and illicit activity are often enhanced by the fact many triads retain profitable links with corrupt police and government officials.

Triads often operate as franchise-type organisations and as long as members pay their dues they can act independently. Triads were partially financed by franchising street violence to linked street gangs who then assisted in intimidation and violence targeted toward both legitimate and illegitimate businesses in Hong Kong. Contract enforcement, debt collection and the elimination of competition were key and highly publicised violence helped build reputations whilst maintaining compliance and discipline. The long term success of triads was also based upon long-established and sub-cultural aspects of loyalty, secrecy and brotherhood and this forms the basis of internal discipline which, according to Paoli (2002), is the foundational discipline of such societies. The use of rituals is notably for initiation, but is still believed to take place in triads though it is often a mystery, (Covey, 2010). Similar codes of honour adopted by triads are sometimes found in street gangs (Lee et al 1996).

It is really only when the triads become involved in violent crime do we get an insight into their links with organised crime. Paoli notes that triad societies are "not exclusively criminal organisations but are multi-faceted brotherhoods in the form of loose cartels bound by social as well as economic ties' (Paoli 2010, p2). Not all criminal groups or criminal network in Hong Kong are triad related. Triads can be compared in some ways to the Sicilian mafia according to Broadhurst and Wa (2010, p3).

\section{Expansion and Displacement}

It is widely reported by academics and the media (China Daily - 29th Dec 2012) that Hong Kong triads are now pushing north into mainland China largely due to a Hong Kong police crackdown and also the opening of new and potentially unexploited, lucrative opportunities. Hong Kong is also believed to be at saturation point with high commercial rents and greater competition for making money. This has led Hong Kong triads to start using Guangdong province as the back-office location for storing drugs, manufacture and storage of counterfeit goods such as fake credit cards.

Local triad meetings and rituals are still conducted in Hong Kong and the regular commercial and public traffic between Hong Kong and Guangdong makes it all but impossible to detect these activities. Hong Kong police estimate approx 3,000 active Hong Kong triad members are operating on the mainland and mostly in Guangdong province. Triad operations in Hong Kong have also not really declined despite the police crackdown. Groups such as Sun Yee On, 14K and Wo Shing Wo are all said to be active in Shenzhen, Huizhou and Dongguan, (China Daily - 29th Dec 2012).

In Guangdong, recent triad operations are noticeable through a range of incidents, e.g. a notorious gangland execution in 2007 which took place in the famous Luk Yu teahouse in Hong Kong; a senior triad boss shot in Dongguan; an assassination plot in Shenzhen to kill the founding chairman of the Hong Kong Democratic party. Other Hong Kong triads spread out to Macao for lucrative gambling receipts and opportunities including managing the VIP rooms at casinos in the city. For example, the Wo triad with its factions of Wo Shing Yee, Wo On Lok and Wo Shing Wo are the longest established triad in Hong Kong boasting an estimated 20,000 members. Criminal activities such as junket operations for high rollers, and loan sharking make up their main income, (China Daily - 29th Dec 2012). Network links between Macao and Zhuhai also permit members to lie low in mainland China if police activity in Macao becomes too problematic. In the pre-handover months in Macao some 14 people were killed by wars between triads and the leader of the notorious 14K group, ('Broken tooth') Wan Kwok-koi, served 
15 years for gang related activities. The Chinese control of Macao is now thought to be considerably stronger than in the pre-handover days.

One former Hong Kong police officer with 30 years experience of working with triads states that 'triads can only be operated against. They can never be eliminated. It's like a poisonous fungus. After you've plucked it, it grows back again'. Moreover the triads operate with lucrative business returns. This means that if one triad folds then others will step in to take over the business and start it up again, (China Daily - 29th Dec 2012).

\section{Triads and Street Youth Gangs}

Through cultural representations and more recently via films, Triads have been romanticised by the Chinese as noble cultural societies operating to the Chinese code of Confusion philosophy, (Covey 2010). From this elevated vantage point they can offer a template to younger, more loosely affiliated street gangs who in turn can act as fertile ground for recruitment into triads. The relationships here are not fully explored and often remain contested.

Main (1991) views triads as operating on a spectrum from loosely based street gangs to highly organised criminal networks. Chu $(1994,2000)$ however suggests triads operate as a pool of potential associates who come together for criminal activities. He identifies the street gang as the lowest tier of this hierarchy, reporting via their gang leaders to area bosses, who in turn were controlled by chairmen. In this interpretation, Chu viewed the street gang as operating with a high degree of organisation compared to the loose social networks of acquaintances operating at the higher levels.

As a result the degrees of 'control' exerted by triads on street gangs may vary by context and by situation, though it seems commonly agreed that street gangs operate as contractors for the triads in some business arrangements (Covey 2010). In this way we may view the relationship between the street gang and the triad in much the same way as Western academics have viewed the relationship between the urban street gang and organised crime, (Thornberry, Densley, Shelden et al 2001).

The triad is headed by adults however it enlists younger recruits to help sustain its criminal interests. Youths may find it offers powerful protection to them with valuable social contacts and often youths then seek to enlist. Whilst enlisting may involve some form of ritual, even those who do not formally enlist often claim to be acting in or for a triad and can name their gang as a form of triad franchise or branch of the society. Street gangs can at times imply connections or links to triads to impress or ward off other rivals. Police often have difficulty in determining real triad societies from bogus or falsely claimed ones, (Ngai, Cheung \& Ngai 2007).

Broadhurst and Wa (2009) agree that triads will hire street based youth groups to help protect illegal enterprises; a view supported by both Chin and Zhang 2003. Triads can also be linked with businessmen involved in racketeering, but often these are loosely connected. It is however street gangs that are responsible for street level violence. In this way young men from poor and deprived neighbourhoods provide the lowest tier of the triad society with triad adults recruiting from such neighbourhoods. These adults often act as a successful role model for new recruits or Wannabees recruits, although the age of recent arrestees for violence associated with triads does however suggest that triads might be losing attraction for younger Hong Kong youth.

The links between triad societies, crime networks and youth street gangs have been researched by Lee (2005) and described by Broadhurst and Wa as 'a dynamic form of symbiosis between triad groups, criminal entrepreneurs and delinquent businesses, officials and professionals ... associated with triad-related 
violence', (2010, p20). Central to this is the 'mutual aid orientation' commonly expressed amongst triad societies and their role as 'protector' in the overall command structure of illegal and criminal enterprises. Although some have become niche operators in the protection business whilst others are more favoured as negotiators or financiers. At times this role would expand to include extortion and even generate its own criminal outputs.

Broadhurst and $\mathrm{Wa}$ (2010) contend that to expand their shared interests, exploit business opportunities and see-off rivals, these triad societies developed a simple command structure. This usually involved a specialist leader holding strategic governance over the society but linked to underworld criminal networks. Such men are highly skilled operators networked through Guanxi. Their ability to quickly muster multiple thugs to act as the 'strong arm' for the enforcement of protection rackets became a regular feature of the presence of triads.

Competition between triads leads occasionally to sporadic violence and ability to organise quick mobilisation is a reputational benefit. Reputational enhancement of triad groups forms a version of 'street capital' (Harding 2015) and defence of earned reputations can also trigger violence. Other disputes occur over territory.

Lethal violence is reportedly declining. According to Broadhurst and Wa (2009) in 1997 approximately 25 per cent of all homicides were linked to triads but by 2001 this has dropped to 5 per cent, and no definable links were evidence by 2004. Fortunately triad linked homicides are infrequent thanks in part to the strict control of firearms. Broadhurst and Wa (2009) report that 50 per cent of the homicides that occurred in the period 1989- 1998 were related to lower-rank street-level confrontations over honour or territory; 21 per cent of homicides were related to business rivalries between competing illicit entrepreneurs; enforcement of 'discipline' of customers (for example unpaid debts) accounted for 17 per cent of homicides; internal sanctions or punishment accounted for 14 per cent and occurred at both street-level ranks and syndicate level ranks.

\section{Changes in Secret Societies}

Changes in the political economy in Hong Kong (moving from a manufacturing economy to a financial services economy) and the end of colonial rule have led to changes in the roles and functions of the triads. Essentially triads have adapted to these socio-economic changes and have had to both modernise and transform. Broadhurst and Wa claim the aims of the triads 'have become corporatized and boundaries moved beyond traditional predatory street crime, extortion and drug dealing predicated on brand violence to diverse 'grey' business activities that also include trafficking (anything profitable), vice, copyright, Internet and financial service crimes such as money laundering and fraud'. (Broadhurst \& Wa, 2010, p2).

Part of this functional adaptation includes some previous triads activities, such as vice and drug manufacture, moving from Hong Kong to mainland China where triads are likely to experience considerably reduced surveillance and investigation by the police, largely due to high levels of corruption. According to Broadhurst and Wa (2010, p2) this 'shift in the relative visibility and apparent scope of the triads may thus be a form of organisational transformation and displacement stimulated by the absence of capable guardianship in adjacent cities such as Shenzhen Special Economic Zone (SEZ) and elsewhere in Guangdong and China'.

Chin (1990b) found that being associated to a triad in locations such as Taiwan, Macau or HK both grants and improves social capital. As a result 'a degree of overlap and ambiguity between triad society, illicit business and 'organised crime' is inherent', (Broadhurst \& Wa, 2010, p3). 
Both Chin and Zhang argue that amongst the Chinese diaspora triads have been in decline and they cast doubt over the existence of global triad networks, (Chin \& Zhang 2003). Hong Kong retains its place as a major international hub for transport, finance and business though no evidence has been found of any transnational triad organisation. The triads however do control the drug trade at street level. The wholesale trafficking of drugs appears to still be organised by small groups of entrepreneurs. They note that in Hong Kong the involvement of triads in crime has not increased for the past 20 years. In 2006 only 3 per cent of recorded crime was designated as triad related. At present Broadhurst and Wa (2009) suggest around 50 groups are active according to sources in the Hong Kong Police. The Hong Kong police Organised Crime and Triad Bureau undertake routine patrols and surveillance operations sometimes leading to raids against suspect groups. They also undertake community youth diversion projects in Hong Kong.

\section{Operational Adaptations}

Prior to the return of Hong Kong to the People's Republic of China, (PRC), the Hong Kong government established the Organised and Serious Crimes Ordinance (OSCO) in 1994 which created new powers and authority to recoup the proceeds of crime. It was thus aimed at addressing both street-level groups and strategic leaders. Through this route the Hong Kong police targeted money laundering and Boiler Room Fraud cases issuing restraint orders and confiscation orders. The ultimate goal of such activity has been to create a risky environment for triads to operate illegally and to force them to engage in legitimate businesses and business practices. The China Daily has headlined the rise in fraud and warned of the economic impact upon businesses, (The China Daily 20th Feb 2009).

The transformation of Hong Kong's economy into a financial services hub for East Asia has been coupled with a reduced tolerance of triad violence. The old romantic notions of triad societies appears to have a looser grip on the public imagination. The overall effect of the OSCO and other related legislation in the 1990s was to begin a shift from the traditional policing relationships between Hong Kong police and the triads, which partially tolerated them, to one which demonstrates a focussed hostility towards organised crime and attempts to suppress triad subculture. This has had the effect of moving the triads from violence, vice and visibility to reduced visibility and more flexible forms of business enterprise. (Broadhurst \& Wa 2009).

In addition to these internal changes in Hong Kong, specifically how it is policed and the broader business environment, there are wider changes in southern China which have led to new developments and expanded opportunities for triads whilst their influence in Hong Kong has been decreasing.

Triads now appear to operate a more flexible and elastic form of business enterprise with greater emphasis on business and a more open door policy to those wishing to join. This is partially recognised as a business response to the fact HK is now fast becoming a service industry society with fewer local shops and businesses to exhort. Human trafficking between HK and China has also now ended with the handover of HK to China, (Parry, 2013).

The opening of the Chinese economy from the 1980s onwards and the return of Hong Kong to the PRC has helped propel the triads through the growth of illicit trade in goods and services to more competitive markets in southern China. The liberalisation of cross-border traffic from Hong Kong to China helped establish the Shenzhen Special Economic Zone and precipitated the extraordinarily rapid urbanisation of Shenzhen and Gaungdong province. Shenzhen itself rose in population from a few thousand in 1980 to almost 15 million by 2014, (Whitwell, 2014). 
These emerging Chinese mainland markets outstripped the ability of regional legislators and authorities to regulate and enforce the newly developing markets and thus created opportunities for corruption and protection rackets. Access to justice and dispute resolution was limited and for some unobtainable. Crime in Shenzhen soared with 100,000 offences recorded in 2003 and significant rises in homicide, assault and kidnapping, (South China Morning Post, 2004). By 2006 Shenzhen became the gateway city for drugs for southern China, (South China Morning Post, 2006).

\section{Drugs}

Increased urbanisation was spurred on by huge levels of migration from rural areas to the urban cities opening up new markets for drugs, notably heroin, ketamine and methamphetamine. As well as a business opportunity, drug use itself in China remains a national problem.

Drug trafficking and new entrepreneurial drug syndicates have expanded from Hong Kong to Shenzhen and Guangdong province. Though data remains sketchy it is likely that the commercial vice trade which once thrived in Hong Kong has similarly been displaced to Guangdong province. Broadhurst and Wa (2009), note that triads are now actively attempting to enter new markets for criminal activities such as internet gambling, copyright theft, international animal smuggling, counterfeit drugs.

By the end of 2014 China had 2.95 million registered drug users but the actual number is estimated to be more than 14 million, according the China National Narcotics Control Commission (NNCC). The number of synthetic drug users (approx 1.46 Million) overtook the number of registered heroin users in 2014. A total 880,000 drug users were arrested in 2014 with 264,000 entering compulsory detox centres and 197,000 receiving community drug rehabilitation, (China Daily $5^{\text {th }}$ November 2015).

Police have discovered triad gangs were involved in well organised, cross border syndicates. Operation Thunderbolt, jointly operated between Hong Kong, Macao and Guangdong police netted 1,191 people in a month long crackdown on cross -border triads. Gambling dens and vice venues were shut, 40 kilos of ketamine were seized and contraband and counterfeit cigarettes. Kowloon East in Hong Kong had actually noticed a decrease in gang activity since recent court sentences for money extortion such as imposing a monopoly on the purchase of construction worker lunch boxes. In the northern territories of Hong Kong, the main income for gangs comes from illegal gambling. Police noted that some young people were hiring boats for boat trips with friends where they took drugs. Officers from the Crime Prevention Bureau in Hong Kong were seeking to stop triads from recruiting young people, (China Daily 17th Aug 2012).

Cocaine remains expensive and thus less popular in Hong Kong. Nevertheless police smashed a high level and cross-country cocaine tracking syndicate during Operation Vanquisher. Lee (2009) notes that 'over 75 per cent of drug offences by juveniles under the age of 21 yrs typically use Ketamine, whilst cocaine only accounts for approximately 55 of offences'.

Zhang Jun, Vice President of the Supreme People's Court commented that 'a majority of drug crimes are now linked to gangs', (Chuanjiao 2009b). The announcement noted that courts dealt with nearly 44,000 drug cases in 2008 which was up by 12 per cent on the previous year. Drug-related crime was commonly now associated with gangs and violence including a shift in trends from importing ketamine to making it domestically. Raw materials were now often smuggled in and new drugs such as methamphetamine were starting to replace opium and heroin. In 2008 there were 12,243 Methamphetamine related crimes (up 61 per cent) and a further 5,251 from January to May in 2009. This has led to the production of methamphetamine in local apartment blocks and the greater use of gang affiliated youth to deliver and manufacture such drugs. Criminal law in China for smuggling, trading, transporting, manufacturing or 
trafficking drugs or even possessing drugs $1 \mathrm{~kg}$ or more of drugs is liable to a minimum of seven years imprisonment. The death penalty is instigated or larger amounts. This type of criminal activity is most commonly located in the provinces of Guangdong, Gaunxi, Yunnan, Sichuan and Guizhou. The Supreme People court has recently toughened its sanctions for those involved in drug offences with new unified capital punishment sanctions for those involved in trafficking using force, international drug trafficking, instigating minors to deal drugs, or those providing premises for drug manufacture, (Chuanjiao 2009b).

\section{E-Crime}

Other operational adaptations include the move into Internet crime with some 'e-crime' gangs now targeting older women and approximately 70 per cent of victims are elderly and female. Often they are tricked into releasing bank account details. A crackdown found gangs operating out of six counties in mainlined China using connections to Taiwan and southeast Asia to avoid detection. More than 1,400 suspects were recently detained due to suspected involvement. According to news reports, 'The gangs act like corporations with departments in charge of technology and others in charge of transferring the money', (China Daily 31th Aug 2009).

\section{More Talk, Less Fighting}

One noticeable outcome in Hong Kong has been a recent change in how triads operate. This is noticeable in terms of visibility, levels of violence, influence and ways of operating. Some leading triad members have shifted their focus from illegal business into quasi-legal business.

Deng, (2012), writing in the China Daily, reports that 'the city's triad menace related to youth gangs is abating, thanks in large part to the efforts of the police to crack down on the violence, and social workers 'to encourage many young gang members to give up the criminal lifestyle and go straight'. Deng notes that rival gang groups of up to 100 youth would congregate for fighting whilst others became involved in taking ketamine and then playing gaming machines.

To address such issues, the Hong Kong Federation of Youth Groups has been working with 200 'at risk' teenagers. Their activities have reduced the impact and threat of violence from such groups compared to a year ago according to NGOs. The social work outreach team have worked with young kids trying to get them to desist from gang membership. As one youth worker noted back in 2011,

Three nights out of seven we could see triad fights or looting in the neighbourhood. Not all incidents were reported to the police. Sometimes you could see a gang of 40 kids dressed in black hanging out in the basketball court. You could see them in the shopping arcades. (Ken Yeung, a youth worker from Won Tai Sin Outreaching Social Work Team).

In 2010, 30 young people under 20 were arrested and charged with wounding and a further 82 with assault. At Easter 2011 police and social workers were struggling to keep up with referrals and fights mostly between those 14- 19. In 2011, 30 were charged with wounding and 63 with serious assault according to the Police Public Relations Branch in Hong Kong, (Deng, 2012).

Local police operate with informers but resolving issues via the police is not common as many triads settle conflict via cash payments. It is apparently not uncommon for a gang member suffering grievous 
injury to withdraw his accusation saying he can no longer recognize who inflicted the wounds, (Deng 2012).

The reduction in violence or the reduced inclination to violence has also been noticed by Sociologist Lee King Wa from Chinese University in Hong Kong. He believes the move away from violence is partly due to policing tactics and partially due to a desire to invest in local businesses and cross-border schemes such as the trade in milk powder. He believes that the move into legit businesses has interrupted the triad chain of command as lower-ranks sometimes now act independently without the counsel of the Big Brothers, (Parry, 2013).

This view is supported by other academics who note it has become more difficult to recruit foot soldiers: 'In terms of structure they (the gangs) are not as organised as in the past. They used to be more concerned about the Brotherhood...that made it easier for them to recruit foot soldiers to commit crimes for them - but now it is getting more difficult', (Sharon Kwok of City University, Hong Kong, (Parry, 2013).

Whilst younger triad members will often do work for the Brotherhood (triad elders) without pay, Parry (2013) reports that now on occasion youngsters will be paid by triad members just to show up in a show of strength against rivals.

There are some indications that violence, although less frequent, is perhaps now sporadic and uncontrolled. Parry, (2013), reports that lower level triads, which often recruited from schools in large quantities to keep the triad societies thriving over the past 20 years, now sometimes operate outside the control of their bosses. This in turn leads younger members to get involved in violence because they are now less controlled by the older Brothers than in the past. Previously they would seek permission to fight however now they may just fight if they wish to. Also there are reports that they are less picky in choosing members and have different members in different areas. As the juniors recruit their own members the seniors are often cut off from this new network. This view has been supported by other authors such as Lee Kwing-wa, sociologist at the Chinese University of Hong Kong. As he mentioned, Triads now 'talk more and they fight less. They are more calculating, more rational, and it is less about sub-culture and Brotherhood. They talk more about benefits. Different triad groups work together to get business done',(Parry, 2013).

\section{Characteristics of Youth Gangs in China}

Chinese studies have begun to decipher the different emerging characteristics of youth gangs in China which permits us to summarise the knowledge as follows:

\section{Prevalence}

During the 1950s and 1960s youth gangs in China were not considered a problem. Their presence was reported at being as low as 6 cases per 100,000. However by 2005 this had risen to 356 per 100,000, (Zhang, Messner \& Liu, 2008). Urban street gangs have in fact been developing and emerging in China since the 1970s and 1980s (Zhang $2002 \&$ Zhang et al 1997) suggesting socio-economic reforms created the climate for street gangs to emerge. However as in the West, statistics are clouded by definitional difficulties, interpretation and collation reluctance, denial and central authorities reluctance to honestly reflect the situation in some cities least they be assessed by central government as under-performing (Covey 2010). 
Despite this, it appears that the huge economic developments occurring in China over the last 30 years have been mirrored by cultural changes and sifting patterns of crime, notably juvenile delinquency and increased patterns of offending (Zu-Yuan 1998). Although formal and official data remains elusive, Xiang (1999) identified that approximately 7 per cent of youth delinquency was in fact gang-related. More recently in 2008 Zhao (2008) reported increased gang activity in China.

Cao and Dai (2001) have noted that economic changes have led to increased anomie in China alongside considerable inequality between rural and urban areas and also specifically within urban areas. These social changes allow the expression of individualism and personal freedoms with ideological expectations now diminishing alongside the ideological control that was so associated with China's communist rule.

The prevalence of gang involvement in China and gang participation in the West was recently examined by Webb et al (2011) by undertaking a self-reporting study amongst school groups. Results indicated that the US sample displayed a higher prevalence of self-nominated gang membership than in China. The Chinese sample was also lower in 'last year' and 'life time' participation in various criminal activities than in the US sample. As might be expected due to the different cultural and social contexts, there were also definitional challenges re the term gang.

\section{Delinquent Behaviour and Gang Involvement}

A recent study by Pyrooz and Decker considers the relationships between delinquent behaviour and gang involvement in China and involved gathering self-reported data from 2,245 school youth in Changzhi in northern China. They found over half the respondents engaged in some form of delinquency in the previous year with 11 per cent reporting gang involvement. Current or former gang members had higher likelihood of overall delinquency and specialisation in violence. Pyrooz and Decker (2012) found that the relationship between gangs and violence, delinquency and offending were similar to those found in the West.

There is no history of self-reported gang studies in China as there is in the US and any use is limited, (Zhang 2008). Webb et al (2011) however did undertake a study of school youth using self-reported questionnaires using the International Self-Report Delinquency (ISRD-2) questionnaire to undertake a comparative analysis between China and the US. Here Pyrooz and Decker (2012) found Chinese youth had lower levels of self-reported delinquent behaviour and lower levels of self-reported gang membership than US youth. However those that did self-report as gang-affiliated reported greater levels of offending and victimisation.

Pyrooz and Decker (2012) argue that results from their self-reported study of Chinese school youth indicate that established criminological theory to explain delinquency can be applied to Chinese youth. They also maintain that parental monitoring, parent and school attachment, peer association and low self-control were correlated with likelihood to offend and specialise in violence.

\section{Organisation}

In China youth crime gangs (qing shao mian fan zui taun huo) are considered to be loosely connected groups of males aged between 14-25 yr involved in criminal offending, (Zhang (2014). Youth street 
gangs are thought to differ from organised crime due to their fluid membership, limited cohesion, limited level of organisation and varying definitions of co-offending and group offending particular to China.

Chinese studies have recently come to view contemporary youth gangs in China as more organised and more violent, more technology oriented and engaged in wider types of criminal activity than in the past (Zhang 2014); as a result youth gangs are now an issue of public concern for many Chinese.

To determine levels of organisation within street gangs, Zhang L. (1997) compared both China and US using data from an inmate survey in Tainjin, comparing youth gang characteristics, types of offences and criminal justice responses. Findings show that the level of organisation in a Chinese gang is low compared to the US and that most activity is from mid-teens to early twenties before levelling off - this is consistent with US research. The study of inmates in Tianjin prisons and reform camps identified four key characteristics of gangs in China. Firstly the level of gang organisation is said to be low. Secondly membership is age-graded and often transitory. Thirdly gangs were territorial and associated with clearly defined spatial neighbourhoods. Lastly offending was what Malcolm Klein (1995) would call, 'cafeteria-style' and often low level.

In a further study by Lee et al (1996) of 36 Hong Kong street gangs, the authors found both core and fringe members and that the gangs were not cohesive. They operated autonomously only referring to triad links when in dispute with rival gangs. As in much gang research there was no mention of the role played by girls.

Chu (2000) remains sceptical of the organised nature of such affiliated noting that street gangs often over-claim allegiance - similar to gang 'wannabe's' in the West.

The Hong Kong Federation of Youth Groups believes that the use of Whatsapp has also changed the ways youth gangs and triads link up and organise. The App brings multiple young people into a fight instantly whereas otherwise they may simply sit at home and play computer games or take drugs in stairways. Triad clashes are mostly internal rivalries within the triad, (Deng 2012).

\section{Membership}

Some differences between western gangs and those in China are more are evident. In China 'Fellow workers' and 'provincials' are a 'relatively common' source of gang membership. This interesting difference reflects the unique social structure of China particularly regarding employment and migration. As found in Russian street gangs and youth groups in China, the workplace often acts as the centre of association and occasionally gang formation (Zhang (2002) and Zhang et al 1997).

Also gang membership does not appear to be correlated to the seriousness of the offense or reason for incarceration - this differs from the USA. Lastly gang related crime does increase the severity of punishment. This is in line with current official policy of cracking down on gangs, (Zhang 1997). Matheron (1988) also noted that street gangs can act as a 'probationary period' for some young gang members before permission to full tiered membership.

Other observations by Zhang (1997) about Chinese street gangs reflect similar gang structures and hierarchies and membership as found in the West; i.e. gangs are largely male, aged between 15-25 with core and peripheral membership and links to local city or neighbourhood territories. Whilst free gang association is always an option many Chinese youth prefer to join gangs associated with triads (Che 1992; Wong 1999). 


\section{Loyalty}

Chinese studies have identified that youth bond together for common support, common interests, protection, and engage in anti-social behaviour, (Zhou et al 2004; Liu, 2004, Zhang 2014). They also group together for joint criminal enterprise and act together out of bonds of loyalty to friends, which is generally considered to be a 'primary moral standard' (Zhang 2014) and expected social requirement in China. Indeed the research study of inmates in Tianjin stated that 60 per cent of the respondents cited loyalty to friends as the main reason for gang affiliation.

Zhang (1997) and (Covey 2010) both rightly identify that Chinese moral codes of loyalty to family and friends often underpin affiliation and associations at work as well as in the formation of criminal networks.

\section{Recidivism}

High levels of recidivism were also identified by researchers Zhang and Huang (1984) who undertook research into 100 youth gangs in Guangzhou. They identified that 49 per cent of gang members were recidivists. This is considered important as recidivists were central in overseeing gang recruitment, training, and organising of activity alongside maintaining discipline and solidarity, (Zhang 2014). As the China Daily news reported, 'From 2002 to 2011, the rate of recidivism of China's juvenile offenders remained at 1 per cent to 2 per cent, according to a white paper on judicial reform published in October of 2012', (China Daily 23rd Sept 2013).

Ken Yeung, a youth worker from Won Tai Sin Outreaching Social Work Team, notes that repeat offending within the triad often helps to embed the youngster within the triad subculture. After a while these youngsters find it difficult to go back into normal society. Yeung acknowledges that those who

are more embedded will find it difficult to withdraw and desist and those with chaotic or difficult home lives often stay embedded, (Deng 2012).

\section{Summary}

Wang (2006), Zhang (2001) and Zhou et al (2004) have summarised some key characteristic of Chinese gangs thus: Some gangs have defined leadership however mostly the level of group organisations is low; Membership status is generally changeable and impermanent; membership is based on neighbourhood territory, age and occupation (e.g. co-workers, neighbours, school mates); lastly, criminal activity largely involves crime against property and interpersonal violence, (though some specialise in property or vice, most engage in multiple criminal activity), (Zhang 2014).

\section{Risk Factors for Youth Gang Affiliation}

Chinese research into youth delinquency and gangs suggests that the common risk factors or predictors for delinquency include levels of attachment to school, moral adherence to Chinese culture, harmony between the generations and integration within society, (Wong 1999; Wong 2001; Zhang \& Messner, 1996).

In addition, as identified above, both triads and youth street gangs have been sustained over the years through migration and immigration. 


\section{The Role of Rural: Urban Migration}

The Hukou urban registration system established by the Communist regime effectively initiated a dual system of citizenship separating rural from urban citizens. It prevented rural citizens from becoming urban citizens and was designed to limit migration from rural to urban areas in an attempt to address increasing urbanisation. The economic reforms initiated from the 1980s onwards immediately drew attention to the large surplus of rural labour and the deficit of labour in the expanding urbanised cities. The response was to slacken the restrictions resulting in large migrant movements to the cities. One result, aside from rapid urbanisation, has been a concentration of poor rural migrants in poor and underserviced neighbourhoods, (Zhang 2014). If lucky they will eventually move to cramped multi-occupancy high-rise developments on the periphery of cities.

Citing Adamson (1998) Ngai, Cheung and Ngai (2007) note that the multiplicity of high-rise housing often tends to diminish community integration in neighbourhoods and may thus act as a future catalyst for gang involvement in China.

One example is the influx of migrants into new towns such as Tseung Kwan $\mathrm{O}$ in Hong Kong. This new town had a population of around 100,000 in 1999 and it now stands at nearly 400,000 with 17.5 per cent of the population aged between $10-24$ yrs. A recent survey in the new town by Caritas Youth and Community Service found that half of the 140 teenagers interviewed claim at least one friend who is connected to triads or is a member of a triad; 30 per cent of the young respondents said they had been harassed by triads themselves. Many triads had local influence before the new towns were built as they operated from local villages. The new towns simply provided opportunities for them to expand their power and to recruit new members. However, younger members are often 'fractious and easily provoked'. In Tseung Kwan O, approximately 90 per cent of the triad members are affiliated to Sun Yee On triad, (Deng 2012).

Children from migrant families are not allowed to attend public high schools in cities. In addition to being separated from their parents they often have to undertake their own schooling at home. Whilst some attend primary or middle educational schools, resources and opportunities are limited. Citing a recent Education report from the 21st Century Education Research Institute realised in April 2015, Wangshu (2015) notes that 20 per cent of the 278.9 million children in China were not able to enter public school in 2013. This is despite an order from central government for local government authorities to ensure migrants can enter local high schools, but city authorities who are attempting to control population increases have often tightened their polices and restricted access. The report which sought to analyse China's educational reforms in 2014 noted that around 36.7 per cent of juvenile criminals attend neither school nor work. Around 27 per cent of juvenile criminals are children whose parents leave them at home whilst the parents seek migrant work in cities and a further 27 per cent of juvenile offenders are children who travel with their parents as migrants to work in cities. According to the national census of 2010, around 35.8 million children in China under the age of 18 travel with their migrant worker parents whilst a further 61 million children are left in rural areas when their parents work in the cities, (Wangshu 21st April 2015).

One response of rural migrants has been for young migrants to group together in street gangs. These gangs are largely comprised of youth from the same province, village or town. These regional ties and the Guanxi, or social capital, acquired by family and neighbour ties, act as binding agents for those coming together for criminal activity. 
One high profile article in the China Daily reflected the public debates on migrants suggesting that second generation migrants are not as 'hardworking' as the first and become more involved in crime. Often they realise they have a skills deficit and resort to criminal activity. The Statistics from the People's Supreme Court indicate that in 2007, approximately 316,000 juvenile offenders were sentenced, which accounted for one third of China's convicted prisoners: of these some 87,500 were minors, (China Daily 30th Dec 2008).

In line with the argument of migration leading to increased offending, areas with a high rate of migrant influx, such as Guandong have noticed an increase in juvenile offending. For example in Guangdong, (which has 2 million juvenile offenders accounting for almost a quarter of its total population, from 2003 -2007), the Nanfang Daily newspaper reported juvenile criminal offences increased by 18 per cent year on year. The No1 Criminal Law Court of Jiangsu High People's Court recorded that migrant teenagers were responsible for 87 per cent and 80 per cent of juvenile offences in the cities of Suzhou and Wuxi, respectively. In Zhejiang province in Haishu district, the People's court of Ningbo, (the regional capital) migrant juveniles accounted for 95 per cent of criminal prosecutions. The chief of the Court's Juvenile Tribunal Service was quoted as saying criminals are becoming younger and often have lower educational backgrounds. Approximately three-quarters of juvenile crimes were property related with violence, often including theft and robbery. He further noted that 'crime committed by girls are also becoming crueller and differ less from those of the boys', (China Daily 30th Dec 2008).

In 2009, under the China Daily headline - 'Raising the issue of China's Troubled teens', the investigative reporter Xie Chuanjiao, reported on research conducted by the Beijing Municipal Higher People's court, identified that the majority of juvenile offenders came from migrant families whose children experience poor parental care, neglect and limited educational input. Their study indicated that between 40- 80 per cent of delinquency in the city over the previous three years was by migrant youth with no household registration. Those from single parent homes and those leaving school early were particularly at risk of offending. Of 100 studied cases of young people aged 16-18 years, only 16 per cent of juveniles were attending school at the time of the offence. Property crime, theft and robbery were most prevalent followed by assaults and rapes. Interestingly the report noted bias in schools against migrant students with some being charged extra fees. Guangdong province, (which has by 2009 upwards of 30 million migrant workers) had recently revised its rules to permit migrants who had lived in the province for more than seven years to apply for permanent residence permits. Such permits then allow their children to free schooling for nine years and thus save their parents thousands of yuan. In Shanghai, whilst the rates of delinquency of local youth have remained stable (until 2009), crimes committed by migrant youth has risen by almost 70 per cent from 2004- 2007. The city's Municipal Higher People's Court reported that 800 minors were convicted in 1998, rising to 2,682 in 2007. Of these, 1,833 did not have a local household registration and 86 per cent has no education beyond primary school. Zhang Haitang, the Vice President of the Shanghai Higher People's Court allocated this rise to the increase in migrant population of the Shanghai region which has recently increased by 6.6 million including 604,000 adolescents. It was suggested that traditional community or village groups or organisations assisted in addressing youth delinquency but this proved difficult in peri-urban areas dealing with large numbers of migrants, (Chuanjiao 2009a). 


\section{Social Control}

Wang et al (2002) found that Chinese children whose parents exert strong parental control are less likely to engage in delinquent behaviour, whilst those associating with delinquent peers are more likely to offend. Alongside social control mechanisms and social bond theory, cognitive development, notably academic achievement has been identified as reducing the risks of youth offending in gangs, (Wang et al 2002).

The cognitive and social influences which determine gang involvement have recently been studied by Ngai, Cheung and Ngai (2007) who undertook qualitative interviews with almost 1000 delinquent youth in three cities: Hong Kong, Guangzhou and Shanghai in 1999. All youth were accessed via youth service units, e.g. correctional schools, outreach and social work recruitment. The average age of respondents was 15.8 yrs and mostly male. They identified significant differences between the three cities of Hong Kong, Guangzhou and Shanghai. These differences arise largely due to the different social context of westernized and individualist systems operating in Hong Kong as opposed to socialist and collectivist traditions in mainland China. The results show that the role of parents and the influence of parental control are weaker in mainland China than in Hong Kong however the influence and social control of teachers and the tradition of authoritative control evident in mainland China helps to demonstrate the converse to this finding.

The Ngai, Cheung and Ngai (2007) study found that expected and prior gang involvement of respondents was highest in Hong Kong. Conversely Hong Kong youth demonstrated the lowest scores on youth and friends moral beliefs, parental controls and teacher attachment. Hong Kong youth had higher engagement with social workers. Interestingly the effects of prior gang involvement were noticeably strong in Guangzhou and demonstrated a high predicator of gang activity, (Ngai, Cheung \& Ngai, 2007). The authors claim the findings are supportive of the generality of social control functions, pro-social learning, educational attainment and problem solving abilities on Chinese delinquent youth and their involvement with gangs. The socio-cultural differences highlighted were that teachers and social workers are more authoritative in mainland China and in Hong Kong individual and parental influences are key; even though parents often exerted less control there than in mainland Chinese cites.

The study also found that Hong Kong had the highest level of educational attainment and Guangzhou the lowest. Many respondents in Guangzhou were recent arrivals. In line with reports on migrant families struggling to adapt to newly urbanised conditions, Guangzhou youth tended to be boys with a lower socioeconomic background and had only been resident in Guangzhou for a short time. In this context teachers become the prime authoritative influence and control over migrant youth and possibly one of the few inhibitors for gang involvement. The Cultural hub of Shanghai was noted to have the highest level of further education amongst the youth surveyed, and in this context operated as an inhibitor for gang affiliation (Ngai, Cheung \& Ngai 2007). Xi (2001) argues that in socialist collectivist mainland China, cognitive development plays a lesser role in youth gang desistence than might be expected.

In Hong Kong, maternal education and length of residence in the city were both positive predictors of youth gang affiliation. Parental controls were more effective in gang desistence in Hong Kong and 'attachment to authoritative professionals is more significant in a socialist collectivist country', (Ngai, Cheung \& Ngai 2007, p10). In terms of policy development to address gang affiliation then the authors claim 'bolstering social integration and cohesion in the neighbourhood would be an effective way to deter gang involvement in a collectivist society', (Ngai, Cheung \& Ngai 2007). 


\section{Parenting Practice}

There has been considerable discussion and debate in the Chinese media about parenting styles in China and in particular the unexpected outcomes of the one-child policy. Some believe that China's one-child policy has had a profound effect on parenting practice which in turn has impacted upon youth behaviour and delinquency (Zhang 2014). Zhang argues that Chinese parents develop 'extraordinarily high expectations' of their child, expectations which are often unrealistic and go unmet. For those falling short of this high threshold, or who suffer the stress of fierce peer-group competition, behavioural problems can quickly surface, i.e. this can lead to drug addiction, for others, gang affiliation. Zhang (2014) claims many Chinese parents are more controlling of their children than Western parents and this brings added stress. Chinese parents, he claims, view their children as 'little emperors' within the family and often become spoiled. He suggests this creates a mix of permissive and controlling parenting which generates selfish and impulsive behaviours. Such issues have now become the focus of public debates in China. Indeed some Chinese studies suggest a clear link between such parenting practice and gang related crime and gang affiliation, (Liu 2004; Wang 2005). The All China Women's Federation report that 'left behind migrant children experience lack of security, family closeness, protection and reduced educational opportunities'. This has also led to debates about the influence of social media and TV and also an absence of moral education in favour of academic education, (China Daily 23rd Sept 2013). This however is a topic of little research. What is perhaps clearer is that those who become socially marginalised may drift into gang affiliation.

\section{Recent Changes in Gangs}

Importantly however the link between youth street gangs and organised crime remains rather elusive and further research is required to fully explain this. Despite crackdown, (e.g. Chongqing) there have been no evaluations as to the effectiveness of such policies.

The China Daily reported (27th Feb 2009) that organized crime increased sharply in 2008 despite a government crackdown on gangs according to the People's Supreme Court.

The government is largely unreflexive in regards to youth gang crime and have yet to establish suitable and responsive mechanisms to address them. As a result punishment is based on the pre-established codes for addressing organised crime which tend to be more severe than what might be expected for such collective offending. Despite this, according to recent media coverage, these measures retain high levels of public support.

The general view is that youth gangs have emerged as a social problem in China though their full extent and activities remains somewhat unclear and under-researched, leading Zhang (2014) to call for more research and more theoretical engagement in this research. Pyrooz and Decker (2012) support this

call for more research into group based violence and specialisation in violence recommending greater use of different methodologies to explore delinquency and gang studies.

\section{REFERENCES}

Adamson, C. (1998). Tribute, Turf, honor and the American street gang: Patterns of continuity and change since 1820. Theoretical Criminology, 2(1), 57-84. doi:10.1177/1362480698002001003 
Bakken, B. (2004). Moral Panics, Crime Rates and Harsh Punishment in China. Australian and New Zealand Journal of Criminology, 37(1 suppl), 37-89. doi:10.1177/00048658040370S105

Broadhurst, R. (2012). Chinese 'Black Societies' and triad-like organised crime in China. In F. Alum \& S. Gilmour (Eds.), Routledge Handbook of Transnational Organised Crime (pp. 157-171). London: Routledge. doi:10.4324/9780203698341.ch10

Broadhurst, R. (2013). The suppression of black societies in China. Trends in Organized Crime, 16(1), 95-113. doi:10.1007/s12117-012-9174-0

Broadhurst, R., \& Wa, L. K. (2009). The Transformation of Triad 'Dark Societies' in Hong Kong: The Impact of Law Enforcement, Socio -Economic and Political Change. Security Challenges, 5(4), 1-38.

Cao, L., \& Dai, Y. (2001). Inequality in Crime and China. In J. Liu, L. Zhang, \& S. Messner (Eds.), Crime and Social Control in a Changing China (pp. 73-88). Westport, Conn.: Greenwood Press.

Che, W. (1992). Problems of juvenile delinquency in Hong Kong. Hong Kong: China Book.

Chin, K. (1986). Chinese triad societies, tongs organised crime and the street gangs in Asia and the United States. (Unpublished Doctoral Dissertation). University of Pennsylvania.

Chin, K. (1990a). Chinese Gangs and Extortion. In Gangs in America. Sage Publications.

Chin, K. (1990b). Chinese subculture and criminality: Non-traditional crime groups in America. New York: Greenwood Press.

Chin, K. (2009). Hejiin: Organised Crime, Business and Politics in Taiwan. In T. W. Lo (Ed.), Beyond Social Capital: A Case of Triad Financial Crime in Hong Kong and China. City University of Hong Kong.

Chin, K., Kelly, R., \& Fagan, J. (1993). Methodological issues in studying Chinese gang extortion. The Gang Journal, 1(2), 25-36.

Chin, K., \& Zhang, S. (2003). The declining significance of Triad Societies in Transnational Illegal Activities: A Structural Deficiency Perspective. The British Journal of Criminology, 43(3), 469-488. doi:10.1093/bjc/43.3.469

China Daily. (2001, February 17). Curbing youth crime. China Daily.

China Daily. (2008, December 30). Juvenile crime up among migrants. China Daily.

China Daily. (2009a, February 16). Crime is a risk to stability: Official. China Daily.

China Daily. (2009b, February 20). Economic crime on rise, firms warned. China Daily.

China Daily. (2009c, February 27). Organized crime increases in 2008. China Daily.

China Daily. (2009d, April 28). Crackdown on crime in run-up to National Day. China Daily.

China Daily. (2009e, August 28). Gangs nabbed in Chongqing: 469 still at large. China Daily.

China Daily. (2009f, September 25). Anti-crime sweep smashes 1,300 gangs in south China. China Daily.

China Daily. (2009g, August 31). China’s ‘e-crime’ gangs target older women. China Daily. 
China Daily. (2009h, September 1). Courts convict nearly 13,000 on organised crime charges. China Daily. China Daily. (2009i, December 16). Money-laundering gang trial opens in SW China. China Daily. China Daily. (2012, August 17). Nearly 1,200 snared in month long crackdown. China Daily. China Daily. (2013a, September 23). Teen killers spur discussion on youth crime. China Daily. China Daily. (2013b, September 23). Teen killers spur discussion on youth crime. China Daily. China Daily. (2015a, May 11). Drug users exceed 14 million in China. China Daily. China Daily. (2015b, June 25). String of youth violence cases shocks nation. China Daily. China Daily. (2015c, July 10). Gang activity in Guangdong poses 'serious threat'. China Daily. Chu, Y. K. (2000). The Triads as Business. London: Routledge. Chuanjiao, X. (2009a, May 7). Raising the issue of China's Troubled teens. China Daily. Chuanjiao, X. (2009b, June 26). Gangsters muscling their way into drugs. China Daily.

Cloward, R. A., \& Ohlin, L. (1960). Delinquency and Opportunity. Glencoe: Free Press.

Deng, A. (2011, June 23). Bloody-minded youth. China Daily.

Deng, A. (2012, September 6). Just one of the gang. China Daily.

Dishman, C. (2005). The Leaderless Nexus: When Crime and Terror Converge. Studies in Conflict and Terrorism, 28(3), 237-252. doi:10.1080/10576100590928124

Dutton, M. (1997). The basic character of crime in contemporary China, (Translation). The China Quarterly, 149, 160-177. doi:10.1017/S030574100004368X

Egely, A., \& Howell, J. C. (2011). Highlights of the 2009 National Youth Gang Survey. Washington, DC: Office of the Juvenile Justice and Delinquency Prevention. doi:10.1037/e580942011-001

Harding, S. (2014). The Street Casino: survival in violent street gangs. Bristol: The Policy Press. doi:10.1332/policypress/9781447317173.001.0001

Huang, H. (2007). From the Asian Boys to the Zhu Lian Bang (the Bamboo Union Gang): A Typological analysis of Delinquent Asian Gangs. Asian Criminology, 2(2), 127-143. doi:10.1007/s11417-007-9033-0

Kelly, R., Chin, K., \& Fagan, J. (1993, August). The Structure, Activity, and Control of Chinese Gangs: Law Enforcement Perspectives. Journal of Contemporary Criminal Justice, 9(3), 221-239. doi:10.1177/104398629300900304

Klein, M. (1995). The American street gang: its nature, prevalence, and control. New York: Oxford University Press.

Lee, C. (2009, February 19). Police make largest cocaine seizure in yrs. China Daily.

Lee, F. W., Loi, T. W., \& Wong, D. S. W. (1996). Intervention in the decision-making of youth gangs. Groupwork, 9(3), 292-302. 
Lee, K. W. (2005). Triad-related homicide 1989-1998. (PhD thesis). University of Hong Kong.

Liu, C. (2004). The Characteristics and Causes of Youth Gang crime. Journal of ChangQiu Vocational and Technological College, 11, 55-56.

Liu, J. (2008). Data sources in Chinese crime and criminal Justice research. Crime, Law, and Social Change, 50(3), 131-147. doi:10.1007/s10611-008-9135-3

Luo, S. (2012, December 29). Living on the mean streets. China Daily.

Main, J. (1991). The Truth about triads. Policing: An International Journal of Police Strategies \& Management, 7(2), 144-163.

Matheron, M. S., (1988). China: Chinese triads, the Oriental Mafia. CJ International, 4(3), 26-27.

Ngai, N., Cheung, C., \& Ngai, S. (2007, Summer). Cognitive and social influences on Gang involvement among delinquents in three Chinese cities. Adolescence, 42(166), 381-403. PMID:17849942

Paoli, L. (2002). The Paradoxes of Organised Crime. Crime, Law, and Social Change, 37(1), 51-97. doi:10.1023/A:1013355122531

Parry, S. (2013, November 8). Twilight of the triads. China Daily.

Pyrooz, D., \& Decker, S. (2012). Delinquent Behaviour, Violence and Gang Involvement in China. Journal of Quantitative Criminology, 29(2), 251-272.

Shen, A., \& Hall, S. (2015). The same the whole world over? A review essay on youth offending from the 1980s and youth justice in contemporary China. International Journal of Law, Crime and Justice.

Song, J., \& Dombrink, J. (1994). Asian emerging crime groups: Examining the definition of organised crime. Criminal Justice Review, 19(2), 228-243. doi:10.1177/073401689401900204

Song, J. H. L. (1996). The Asian Factor: Methodological barriers to the study of Asian Gangs and Organised crime. American Journal of Criminal Justice, 21(1), 1996.

South China Morning Post. (2004, January 17). Soaring Crime Rate Dims Shenzhen's Luster. South China Morning Post.

South China Morning Post. (2006, May 10). Shenzhen is Key Gateway for illegal Drugs trade. South China Morning Post.

Spergel, I. (1961, March). An exploratory research in delinquent subcultures. The Social Service Review, 35(1), 33-47. doi:10.1086/640985

Sun, I., Hu, R., \& Wu, Y. (2012). Social Capital, political participation, and trust in the police in urban China. Australian and New Zealand Journal of Criminology, 45(1), 87-105. doi:10.1177/0004865811431329

Thrasher, F. M. (1927). The Gang: A study of 1,313 gangs in Chicago. Chicago: University of Chicago Press.

Varese, F. (2006). How Mafias Migrate. Law \& Society Review, 40(2), 411-444. doi:10.1111/j.15405893.2006.00260.x 
Wang, G. T., Qiao, H., Wei, S., \& Zhang, J. (2002). Adolescent social bond, self-control and deviant behaviour in China. International Journal of Contemporary Sociology, 39(1), 52-68.

Wang, P. (2013). The increasing threat of Chinese organised crime: National, regional and international perspective. The RUSI Journal, 158(4), 6-18. doi:10.1080/03071847.2013.826492

Wang, P., \& Antonopoulos, G. (2015). Organised Crime and illegal gambling: How do illegal gambling enterprises respond to the challenges posed by their illegality in china? Australian and New Zealand Journal of Criminology, O(0), 1-23.

Wangshu, L. (2015, April 21). Migrant life may lead to youth crime. China Daily.

Webb, V. J., Ren, L., Zhao, J., He, N., \& Marshall, I. H. (2011). A comparative study of youth gangs in China and the United States: Definition, offending and victimisation. International Criminal Justice Review, 21(3), 225-242. doi:10.1177/1057567711418825

(2010). What is Organized Crime? InVarese, F. (Ed.), Organized Crime. Routledge.

Whitwell, T. (2014, June 13). Inside Shenzhen: China’s Silicon Valley. The Guardian.

Wong, D. S. (1999, April). Delinquency Control and Juvenile Justice in China. Australian and New Zealand Journal of Criminology, 32(1), 27-41. doi:10.1177/000486589903200104

Wong, D. S. (2004, December). Juvenile Protection and Delinquency Prevention Policies in China. Australian and New Zealand Journal of Criminology, 37(1), 52-66. doi:10.1177/00048658040370S104

Wong, S. K. (1999). Delinquency of Chinese-Canadian youth: A test of opportunity, control and intergenerational conflict theories. Youth \& Society, 29(1), 112-133. doi:10.1177/0044118X97029001005

Wong, S. S. W. (2001). Pathways to delinquency in Hong Kong and Guangzhou (south China). International Journal of Adolescence and Youth, 10(1/2), 91-115. doi:10.1080/02673843.2001.9747893

Wu, Y., Sun, I., \& Hu, R. (2015). Public Trust in the Chinese police: The impact of ethnicity, class and Hukou. Australian and New Zealand Journal of Criminology, (Jan), 21.

Xi, J. (2001). Research reports on China's Youth. Beijing, China: China Youth.

Xiang, G. (1999). Delinquency and its prevention in China. International Journal of Offender Therapy and Comparative Criminology, 43(1), 61-70. doi:10.1177/0306624X99431006

Yoder, K. A., Whitbeck, K. B., \& Hoyt, O. R. (2003). Gang involvement and membership among homeless and runaway youth. Youth \& Society, 34(4), 441-467. doi:10.1177/0044118X03034004003

Zhang, B. (2001). The Characteristics of Youth Gangs. Journal of Fu Jain Police College, 62, 40-95.

Zhang, L. (2008). Juvenile delinquency and justice in contemporary China: A critical review of the literature over 15 years. Crime, Law, and Social Change, 50(3), 149-160. doi:10.1007/s10611-008-9137-1

Zhang, L. (2014). Of Marginality and 'Little Emperors': The changing Reality of Chinese Youth Gangs. In Global Gangs: Street Violence across the world. Minneapolis, MN: University of Minnesota Press. doi:10.5749/minnesota/9780816691470.003.0005 
Zhang, L., \& Messner, S. F. (1996). School attachment and official delinquency status in the People's Republic of China. Sociological Forum, 11(2), 285-303. doi:10.1007/BF02408368

Zhang, L., Messner, S. F., \& Liu, J. (2008). A Critical Review of Recent Literature on Crime and Criminal Justice in China: Research Findings, Challenges and Prospects (Introduction). Crime, Law and Social Change: An Interdisciplinary Journal, 50, 125-130.

Zhang, L., Messner, S. F., Lu, Z., \& Deng, X. (1997). Gang crime and its punishment in china. Journal of Criminal Justice, 25(4), 289-302. doi:10.1016/S0047-2352(97)00014-7

Zhang, L., Messner, S. F., Lu, Z., \& Deng, X. (1997). Gang crime and its punishment in China. Journal of Criminal Justice, 25(4), 289-302. doi:10.1016/S0047-2352(97)00014-7

Zhang, L., Zhang, L., \& Lei, X. (1993). China's Juvenile Delinquency and Justice. Beijing, China: World Knowledge.

Zhang, S. X. (2002). Chinese Gangs: Familial and cultural dynamics. In C. R. Huff (Ed.), Gangs in America III. Newbury Park, CA: Sage. doi:10.4135/9781452232201.n14

Zhang, Z., \& Huang, W. (1984). The role of recidivists in Delinquent Gangs. In Yearbook on Chinese Juvenile Delinquency Studies. Association of Chinese Juvenile Delinquency Study.

Zhou, L., Liu, W., \& Wang, Z. (2004). Contemporary Positivist Criminology: A Study of Crime Patterns. Beijing: Publishing House of People's Courts.

Zie, Z. (2008, December 22). China planning special unit to tackle gangs. China Daily.

Zu-Yuan, H. (1988). China: Juvenile delinquency and its prevention. CJ International, 4(5), 5-10. 